\title{
The Role of Informal Land Dispute Resolution in Conflict Management: Case Study Of Land Dispute Between Bandung City Government And The Local People In Taman Sari Urban Village, Bandung Wetan Sub District, Bandung City
}

\author{
Sait Abdullah ${ }^{1}$, Deni Fauzi Ramdhani², Rofi' Romadhona Iyoega ${ }^{3}$ \\ \{sait.abdullah@stialanbandung.ac.id; denifauziramdani@gmail.com; rofi.r.iyoega@gmail.com\} \\ ${ }^{123}$ Polytechnic of STIA LAN Bandung
}

\begin{abstract}
This paper discusses the informal model in handling dispute mechanism particularly in land conflict between the government and the local people in the Taman Sari urban village, Bandung Wetan sub-district. Several studies on Taman Sari land conflict resolution, indicate how formal mechanism have been utilized in handling land conflict through the use legal channels or formal mediation by involving legal aid institutions, non-governmental organization or involving agencies related to the settlement of community policing such as the TNI, the Indonesian Police force, and Satpol PP. However, to date there has been no study that discusses an informal approach utilized by the Bandung city government in particular, the head of Bandung Wetan Sub-District. This approach actually has a significant effect on the resolution of land disputes. To gather data and information, this study uses a qualitative approach by using focus group discussions (FGD), interviews, library literature studies and government's reports and documentations. The results indicate that a land dispute resolution model by emphasizing the informal approach is very effective in resolving land ownership disputes. This model is potential to become a reference for observers of conflict resolution, especially land ownership disputes in the future.
\end{abstract}

Keywords: informal dispute, conflict, conflict management

\section{Introduction}

Since the beginning of the conflict between the residents of the Taman Sari sub-district and the Bandung City government, researchers have focused a lot on studies and analysis of land dispute conflicts by focusing on the role of formal mediation by involving social workers (Ar-Ridho and Ishartono, 2019) [1]. In handling land disputes in this area, Ar-Rhido and Ishartono (2019) concluded that the role of social workers can become a bridge between the Bandung city government and the residents of RW 11, Taman Sari sub-district. 
Meanwhile, another study conducted by Fahira and Fredryansyah (2021) focused on tracing the root of the conflict in RW 11, Taman Sari Village [2]. By using a problem tree analysis tool. This study succeeded in unraveling the causes of the emergence of the Taman Sari conflict between the residents and the Bandung City Government by emphasizing the aspects of the lack of socialization of urban planning policies through row houses (rumah deret) and repressive actions by security forces. The other research conducted by Purnama (2018) focuses on the adaptation aspect of urban village residents who survived in the case of the Taman Sari conflict in Bandung City [3].

Based on the literature review, the authors found that there was no research which focused on the Taman Sari conflict resolution strategy from the perspective of the Bandung City Government itself. Therefore, this research focuses on how the government, which in this case is driven by the Head of Sub-District or Camat Taman Sari, takes informal approaches to the community in order to reduce the emergence of a larger conflict. The strategy carried out by the Bandung Wetan Camat is very interesting and can be used as an example because the Camat is really concerned with applying informal approaches to the community without violence, without spilling blood but can achieve the target set by the Camat, namely increasing the number of residents' pro-government by achieving the target of $99 \%$, leaving (1\%) one family head who has not agreed with the City government.

The success of the Camat in resolving this conflict is a new finding in the field regarding how an administrator official can help resolve conflicts with the community peacefully. In informal ways a Camat can reduce conflict and make agreements with residents to always support the programs carried out by the government in this case the row house program which has been launched since 2017 informally in resolving land disputes in the Taman Sari sub-district by focusing on the role of the Bandung Wetan sub-district head in using informal approaches to the community of residents of RW 11, Taman Sari Village.

\section{The Concept of Conflict Management}

Administrative officials such as the Camat in the local government often have to deal with conflict situations in carrying out the main tasks and functions of the Camat as a protector of the community. Conflict is something real and something that cannot be separated in our society. Some conflicts that occur in the community are relatively easy to overcome, but there are times when these conflicts really require the role of the leader to immediately resolve them. Allowing the conflict to drag on will make the intensity and scale of the conflict wider and have a negative impact on local government, especially the Bandung City government.

The important thing for leaders, especially the Camat as an administrator, is how to transform a negative conflict into a positive energy for the organization. The central core of conflict is the expression of different perspectives, values and beliefs and perceptions of individuals or groups about something. Conflict essentially forces us to understand that humans have differences and differences are understood as a general characteristic of human relationships in organizations. If managed properly, conflict will make us mature in attitude and behavior in the organization. Therefore, if these middle-level managers understand conflict, of course conflict will develop and teach leadership roles and essential skills in managing conflict in organizations.

Conceptually, Katz \& Mcnulty (1994) defines conflict as a phenomenon in which at least two people or two groups who have an interdependence relationship are aware of differences with each other [4]. Conflict occurs because of differences in interests rooted in differences in perceptions of 
beliefs. and needs produce negative energies that tend to bring each other down. Furthermore, Ohlendorf (2001) defines conflict as a situation in which various parties compete [5]. Conflict occurs when at least one party realizes that there are different interests and needs when it comes to achieving goals. Conflict escalates when actions taken by one party are perceived as causing problems for the other party. Ross (1993) defines conflict management as the steps taken by the actors or third parties in directing the dispute towards a certain outcome that will turn the conflict into a positive, creative, consensus energy and produce a solution [6].

In viewing a conflict, there are two points of view that can be observed, namely from the negative side and the positive side. The two views are a dysfunctional view that views conflict as something that will have a bad impact on the organization, causing chaos and loss of trust in the leadership. While the functional perspective views conflict as an engine of change and a source of innovation as well as bringing productivity and stimulating increased knowledge, skills and attitudes of organizational members. A leader must cultivate creative and innovative thinking and be able to design effective and constructive strategies.

Accordingly, administrative officials need to realize that conflict is something that cannot be avoided in human life. Such is the case with organizational life. Organization members are always faced with conflict. Therefore, before the administrative officials determine the conflict management strategy, they must understand the characteristics of the conflict mentioned above. In general, according to Lan (1997) there are four types of conflict [7]:

a. Unstructured conflict

Unstructured conflict is characterized by the fact that the various parties involved are not bound by various rules and are impulsive and emotional.

b. Fully Structured Conflict

A fully structured conflict is characterized by the fact that the conflicting parties are bound by rules, norms and ethical standards.

c. Partially Structured Conflict

d. Partially structured conflict is characterized by one party still tying himself to the existing rules but sometimes emotions are not controlled.

e. Revolutionary Conflict

f. Revolutionary conflict is one of the extreme forms of unstructured conflict. This revolutionary conflict characterizes conflict on a large scale that is not bound by the same rules, time, culture, myth or point of view.

In order to develop skills for administrator officials in conflict resolution, the first thing that must be done is how these officials are able to map out potential conflicts. Before trying to develop a solution strategy, administrator officials are required to develop related strategic questions such as; Is conflict good or bad for the organization? Or something neutral? At what level does the conflict arise? What is the depth level? Why did this conflict arise? These strategic questions can help administrators in mapping potential conflicts.

The first step in resolving conflict problems is how to diagnose potential conflict problems. This is very important to do before an official administrator finds a solution to the problem. Identify the conflict problem by mapping the types of conflict first by developing questions such as. Are conflicts about resources within the organization, or conflicts related to organizational goals or conflicts related to identity, personal issues or related to the field of work. 
There are several principles that are useful for administrator in dealing with dispute or conflict. According to Katzh and McNulty (1994) there are several principles that must be owned by an administrator in managing conflict, namely [8]:

a. Respect and Integrity

Respect means that a leader looks unconditionally at everyone in a positive light. In dealing with conflict, a leader also acts with integrity. The fundamental perspective of a leader in dealing with conflict is to find a solution.

b. Rapport

An important part of conflict management is maintaining relationships. This includes the ability to create responsive and caring relationships with others. In a conflict situation a leader must be able to create good relations and maintain it in the entire conflict resolution process.

c. Resourcefulness

Leaders must be role models for their subordinates so that they can be used as references to handle conflicts wisely.

d. Constructive Attitude

In dealing with conflict, being positive has become a must for a manager. This attitude is not only useful but important, even in situations where people in conflict use unethical ways to resolve problems. A positive leader can create a conducive attitude throughout the conflict resolution process. This positive attitude is very helpful in achieving a good conflict resolution. Besides principles used by the administrator, there are strategies can be developed by administrators to resolve conflicts within the organization. Starting from direct settlement by administrator officials to using third parties [9].

a. Direct Intervention through Negotiation

If the conflict problems that occur within the organization are related to very technical matters such as conflicts over biased data or information between officials under them or between conflicts, uneven distribution of work between staff. Conflicts like this should be resolved directly by administrator officials by checking the lack of data and then trying to communicate and negotiate with the various disputing parties in order to reach an agreement between the two conflicting parties. There are several skills related to how an administrator can play an active role in resolving conflicts, namely:

- The administrators have to hear a lot from the conflicting parties first

- Maintain a good relationship between the two conflicting parties

- Don't get emotionally involved with the parties in conflict

- Can't lean to one side

- Must be neutral

b. Direct Intervention through Compensation Agreement

It is possible that administrator officials directly involved in conflict resolution can reach an agreement by both parties by applying compensation. For example, if there is a conflict between employees in the context of job distribution or assignment, an administrative officer may provide compensation for those who feel disadvantaged because they do not get a portion of the assignment. He can do this by adding the burden of responsibility but is given the opportunity to handle work that is in accordance with his expertise. 
- Third Party Mediation

If an administrator is unable to resolve the conflict properly within his organizational unit, another way to resolve the conflict is to invite a third party who functions as a mediator or arbitrator. The person appointed as a mediator must have professional expertise in resolving conflicts. The third party is a neutral party, it can be in the form of a psychological consultant or legal consultant or even a court (State Administrative Court).

\section{Methodology}

This research is a descriptive qualitative research. In order to collect field data, this research used interviews, focused group discussions with the Head of Bandung Wetan, Bandung City Satpol PP, Head of the Bandung City Police Department and literature studies of previous studies and used secondary data taken from research reports. This primary and secondary data gathered are very useful for the researchers to sharpen the analysis of informal dispute mechanism used by the Camat Bandung Wetan in resolving conflict with the Tamansari local people.

\section{Discussion}

The actual informal approach taken by the Camat Bandung Wetan is interesting phenomenon to be investigated and become the main finding of the research. The Camat has carefully applied stepby step process in dealing with the people in respective manners. Although the Camat has put forward some informal measures, he understands the planning process regulated by the Bandung City government. Based on data gathered from the Bandung city government, the plan for the construction of row houses in Tamansari sub-district, Bandung Wetan sub-district, was shown in the context of meeting the need for livable houses as well as handling slum areas and alleviating poverty.

This development plan was discussed together in the Workshop of the Tamansari Row House Construction Group in Bandung on April 13, 2017. The row house construction plan in the area has been in accordance with the designation as stated in the RTRW and RDTR, where the row house construction plan has gone through the stages of the auction process. in accordance with the provisions of the legislation. In preparation for the construction of the Tamansari Row House, the Bandung City Government has carried out socialization and approaches to residents.

The approach is carried out in an integrated manner by forming a Working Group for the Tamansari Row House, the Department of Housing and Land and Landscaping Settlement Areas of Bandung City in collaboration with the Bandung Wetan District and Tamansari Sub-district officials, the facilitator for the construction of the Tamansari Row House and representatives of the residents of RW 11, Tamansari Village. Planning Architect, Chairman of the Indonesian Ulema Council, Bandung Wetan District, Public Relations Section of Bandung Wetan City Regional Secretariat, Military District Command 1812 Bandung Wetan About the mechanism and concept of temporary relocation compensation [10]

Table 1. Population Data of Bandung Wetan District [11]

\begin{tabular}{|c|c|c|c|c|c|c|c|}
\hline \multirow{2}{*}{ No } & \multirow{2}{*}{ Kelurahan } & \multirow{2}{*}{$\begin{array}{c}\text { Number } \\
\text { of RT }\end{array}$} & \multirow{2}{*}{$\begin{array}{c}\text { Number } \\
\text { of RW }\end{array}$} & \multicolumn{3}{|c|}{ Total population } & \multirow{2}{*}{ Area } \\
\hline & & & & Man & Woman & Total & \\
\hline 1 & Tamansari & 115 & 20 & 12.457 & 13.378 & 25.835 & $166 \mathrm{Ha}$ \\
\hline
\end{tabular}




\begin{tabular}{|l|l|l|l|l|l|l|l|}
\hline 2 & Cihapit & 36 & 8 & 3.317 & 3.738 & 7.055 & $200 \mathrm{Ha}$ \\
\hline 3 & Citarum & 46 & 8 & 1.722 & 2.103 & 3.825 & $186 \mathrm{Ha}$ \\
\hline \multicolumn{2}{|l}{ Kecamatan } & 197 & 36 & 17.496 & 19.219 & 36.715 & $552 \mathrm{Ha}$ \\
\hline
\end{tabular}

Head of Bandung Wetan Sub-district, Bandung City (2021)

From the 198 heads of families in RW 11, Tamansari sub-district, Bandung sub-district, there are 176 heads of families who have agreed and have been relocated with details of 84 building owners in which there are 153 heads of families plus 23 heads of families who rent a house in RW 11, Tamansari sub-district. For residents who still reject the Tamansari Row House Construction Plan, mediation has been carried out by Komnas H16 November 2018, further mediation by Komnas HAM in the Central Room of Bandung City Hall, led directly by the Deputy Mayor of Bandung, with a decision from the Commissioner of Komnas HAM that the task of Komnas HAM is to carry out Mediation has been completed, the decision is returned to the residents who have not agreed with the Bandung City Government, with 3 offer options: Residents receive money (uang kerohiman) according to the calculation scheme that has been made by PT. Sartonia Agung and the residents have the right to the row house units which will be completed later; or Residents receive replacement money for buildings that are owned independently with a calculation scheme of $80 \% \mathrm{x}$ Real Building Area whose calculations are based on an assessment/assessment by a professional independent appraisal, and residents do not have the right to get compensation. Provision of rental houses for 15 building owners inhabited by 33 Heads of Families affected by asset security in the amount of IDR 26,000,000 (twenty-six million rupiah) for (1) one rental house unit per year.

Based on the results of an interview with the Bandung District Head, Wetan, that the main tasks and functions of the sub-district are to coordinate community empowerment, coordinate public peace and order, coordinate the maintenance of infrastructure and public service facilities, coordinate the implementation and enforce laws and regulations and foster village government in their working areas. In an effort to overcome the problem of conflict with the people of the Bandung Wetan Sub-district, first mapped the potential for conflict by identifying the conflict of interest of the pros and cons of the residents, the cons of asking for high compensation, problematic land status, the length of the development process and the problem of disrupting the socio-economic ecosystem.

In an effort to anticipate conflict, the Camat Bandung Wetan took informal steps by approaching residents through persuasive and familial socialization to residents who were against the government' planning, dispatching the Sub-District Team to secure development activities with residents who were pro-governments, always coordinating with the city planning, monitors and implements security in the implementation of development in Tamansari area. The steps taken by the Camat are very effective so that the city planning development can be carried out, the number of residents who are against city planning, there is no horizontal conflict between the pros and cons.

A persuasive and familial approach to residents who refuse related to the reasons, objectives, and benefits of the planning Development to community members. Free medical treatment was held for residents who refused, shared meals, community service, residents and morning prayers together with the insertion of discussions related to the policy. With informal approach steps in conflict resolution, the construction of the Tamansari Row House has entered Phase 1 of Development which has reached $56.61 \%$ of the construction of the building structure in Block A and Block C. There is only 1 family who has not agreed with the construction of the building (previously 13 families who refuse). 


\section{Conclusion}

Based on the results of the study, it can be concluded that in the context of resolving disputes over land conflicts between the Bandung City government and the residents of RW 11 Taman Sari sub-district, Bandung Wetan District, the Bandung City Government has combined efforts to resolve disputes both formally by carrying out formal socialization efforts to residents and carrying out formal mediation involving the Legal Aid Institute or LBH.

However, the informal methods used by the Bandung Wetan Sub-district Head by using direct humane approaches to the community should be used as a breakthrough for conflict observers because it is proven by informal ways that the escalation of conflict with the residents of Taman Sari has decreased drastically and the target for the construction of the Taman Sari Row House is can be carried out and the affected communities have received compensation both from the developer (the Company) and from the Bandung City government. This in one of the important finding that the researchers gain from the study and the informal mechanism approach taken by the Camat Bandung Wetan can become an important strategy for the administrator in resolving dispute with the local people.

\section{References}

[1] Ar-ridho, Ali and Ishartono. (2019). Konflik Kepentingan Lahan Warga RW 11 Tamansari dengan Pemerintah Kota Bandung Dalam Kasus Realisasi Program Rumah Deret. Jurnal Kolaborasi Resolusi Konflik. Volume 1 Nomor 2. Hal. 70-141

[2] Fahira, Tella and Muhammad Ferdyansyah. (2021). Analisis Konflik Sengketa Lahan di Kawasan Kelurahan Tamansari, Kota Bandung Menggunakan Pohon Konflik. Jurnal kolaborasi Resolusi Konflik. Volume 3 Nomor 1. Hal: 86-92.

[3] Purnama Fiqih R. 2018. Adaptasi Warga Kampung Kota Yang Bertahan Dalam Konflik Penggusuran (Studi Kasus: penggusuran Kampung Kota Tamansari Bandung. Skripsi. Universitas Katolik Parahiyangan Bandung

[4] Katz Neil and Kevin McNulty. 1994. "Conflict Resolution" Available at: https:/www.maxwell.syr.edu/uploadedFiles/parcc/.../Conflict\%20Resolution\%20NK.p...

[5] Ohlendorf. 2001. "Conflict Resolution in Project Management". Available at:

[6] Ross, Marc Howard. 1993 The Management of Conflict. . New Haven, Connecticut: Yale University Press, pp. 226

[7] Lan Zhiyong. 1994, “A Conflict Resolution Approach to Public Administration”. Public Administration Review, 57 (1): 27-35. Wiley, the American Society for Public Administration. Available at: http://www.jstor.org/stable/976689.

[8] http://shiftindonesia.com/lima-langkah-penerapan-dmaic/

[9] Lembaga Administrasi Negara. 2019. Modul Manajemen Konflik

[10] The Bandung City Governemnt Report, 2021: Kronology Penanganan Conflict Taman Sari 